\title{
Modelling Continuous Anaerobic Digestion of Municipal Solid Waste in Biogas Production
}

\author{
Asinyetogha Hilkiah Igoni", Ibiye Sepiribo Kingnana Harry \\ Department of Agricultural and Environmental Engineering, Faculty of Engineering, Rivers State University of Science and Technology, \\ P.M.B. 5080, Port Harcourt, Nigeria
}

Copyright $\mathrm{C} 2016$ by authors, all rights reserved. Authors agree that this article remains permanently open access under the terms of the Creative Commons Attribution License 4.0 International License

\begin{abstract}
In this study, mathematical models were developed for the anaerobic biodegradation of municipal solid waste (MSW) in Port Harcourt metropolis, Nigeria, in a continuously stirred tank bioreactor. The MSW in Port Harcourt is presently not treated before final disposal. The need to incorporate a treatment element into the management scheme has elicited various treatment proposals, including the anaerobic digestion of the waste in a continuous processing system, in order to generate biogas in the process. Bench-scale experimentation was conducted to investigate the behavior of the waste when subjected to anaerobic decomposition in a continuous reactor, leading to the formulation of process models. The development of the models was based on a material balance analysis of the continuous anaerobic biodegradation processes. The models were simulated over a range of fractional conversion $(\alpha)$ of 0.2-0.8 and percentage Total Solids (TS) concentration of 4-10 using the Microsoft Visual Basic Version 6.0 computer programming language. The results of the simulation were further analyzed with the Microsoft Chart Editor, which was used to establish relationships between the various process parameters, including the fractional conversion, time of digestion, effluent substrates and microbial concentrations, volume of gas produced and effluent substrates stabilization. It was found that, whereas the effect of ' $\alpha$ ' on the time of digestion is a logarithmic function of the ' $\alpha$ ', it is linear for the effluent substrate and microbial concentrations and a power function for the total volume of biogas produced.
\end{abstract}

Keywords Anaerobic Digestion, Continuous Bioreactor, Municipal Solid Waste, Biogas Production

\section{Introduction}

\subsection{Municipal Solid Waste Load in Port Harcourt}

There is massive generation of municipal solid waste (MSW) in Port Harcourt (PH), Nigeria. Several studies have determined the quantity and characteristics of this MSW and its adverse impact on the environment and health of the people. Igoni et al [1] investigated the state of MSW in Port Harcourt and found that $1,505,106 \mathrm{~kg}$ of the waste was generated daily, giving a per capita generation of $1.11 \mathrm{~kg} / \mathrm{capita} /$ day, when related to the 2003 demographic figure of $1,356,000$ persons for the city. The current projection of waste load in the metropolis is about 2,000 tonnes per day, with a population of $1,754,175$ persons, at a $2 \%$ annual incremental factor [2]. This huge quantity of waste generated consistently overwhelms the capacity and capability of the Waste Management Authority in its collection and disposal bid and continually keeps the city filthy; turning the city of Port Harcourt from its hitherto generally acclaimed status of a 'garden city' to a new and debasing nomenclature of 'garbage city' [3].

\subsection{Management of MSW in PH}

The current waste management practice involves, essentially, collection and disposal, as there is no facility and provision for treatment, which is a major functional element of any solid waste management system. Even in the attempted efforts, the rate of generation of the waste is always higher than the rates of collection and disposal. This culminates in large amounts of waste remaining on roads unattended. This is so because there are no appropriately defined receptacles for waste. So the wastes are either just littered by the corner or on the median of roads, as they are usually not bagged. As the deposition of the waste on the road persists without a commensurate collection, the waste heap increases and disrupts human and vehicular traffic. Furthermore, it elicits additional hazards like flooding, arising from blockage of drains by the waste; traffic congestion and accidents; offensive odors; destruction of road infrastructure and environmental aesthetics; and pollution of ground water. Getahun et al [4] cites Adeoti et al 
[5] and UNEP [6] in stating that MSW generation has become an increasing environmental and public health problem everywhere in the world, particularly in developing countries because of rapid urbanization and population growth. They explain that, despite the increasing waste load, waste management efforts in these countries are limited to only collection and transfer for which funds are provided; and that, as a result, there is pollution of the atmosphere, soil and ground water due to greenhouse gas (GHG) emissions and toxic leachate [7]

The adverseness of the mounting waste load is exacerbated by inadequate management strategies. Getahun et al [4] referred to Collivignarelli et al [8] and said that low technical experience and financial resources are part of the myriads of challenges that solid waste management bodies have to contend with in discharging their responsibilities. But, beyond this is the critical issue of the absence of waste treatment facilities or even a consideration of the waste treatment component for the management of MSW in most developing countries, especially Port Harcourt, Nigeria. Igoni [2] had reported that even the services of collection and disposal undertaken by the waste management agency are improperly executed.

The absence of the treatment component in the waste handling process increases the burden of its management, as there is no arrangement to reduce the waste load in its quantity and pollution potential. When MSW is treated, the quantitative and pollution loads are reduced, thus reducing its effect on public health and required landfill space for final disposal. In addition, energy is generated in the course of waste treatment. Thorin et al [9] state that waste is a heterogeneous energy source and different types of waste can be converted to different energy products in different conversion processes. Therefore, treatment of the MSW would tremendously mitigate some of the identified hazards of its current poor management and also yield useful by-products, especially energy.

\subsection{MSW Treatment Processes}

Waste treatment and conversion into useful end products are generally accomplished via either biological or thermal processes, which convert the feedstock into energy using microorganisms and high temperatures respectively. The waste to energy conversion pathways are schematized in Figure 1.

There are a number of factors that determine the applicability, efficacy and relevance of these conversion processes for any waste treatment. Prominent amongst them is the property of the waste. Whereas thermal processing is easily adaptable to waste with high percentage of combustible components like plastics and papers, biological processes are better suited for waste with high organic content. Cheng and $\mathrm{Hu}$ [10] found that developed countries have MSW rich in combustible materials, while that of low and middle income economies has high organic component. The organic component of MSW in developing countries is up to $60 \%$, in addition to the high moisture content of the waste, which is up to $50 \%[11,12]$. For Port Harcourt, Nigeria the organic content of MSW has been determined as $69.3 \%$, with an average moisture content of about $20 \%$ on dry basis [1], hence the biological processes are more applicable. Furthermore, for optimal utilization of the waste for energy recovery, as depicted in Figure 1, the anaerobic digestion (AD) process is a better option.

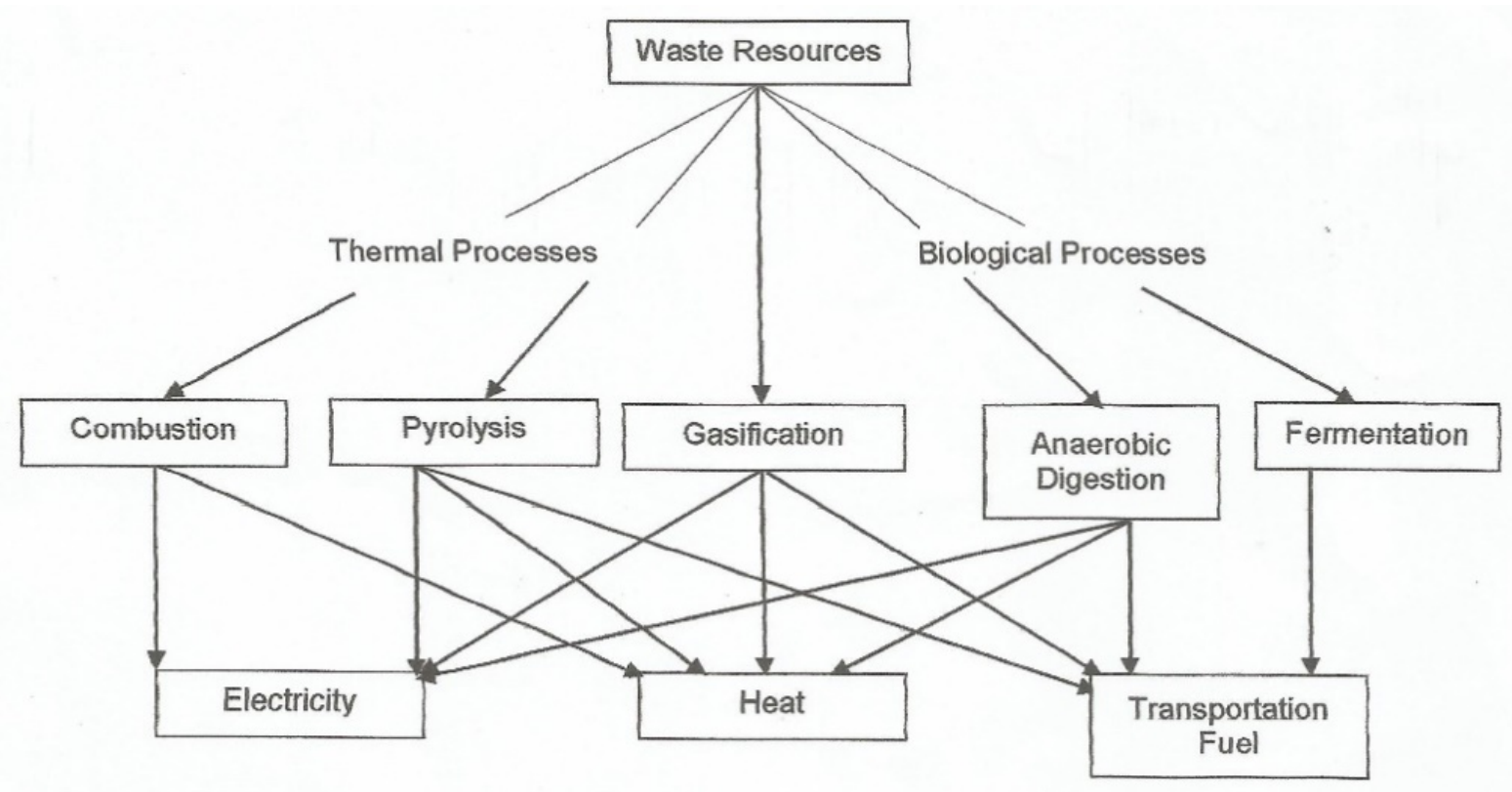

Figure 1. Waste to energy conversion pathways Adopted from Thorin et al [9] 


\subsection{Basic Concept of Anaerobic Digestion}

Anaerobic digestion, also known as biomethanation, is basically the degradation of organic materials by microorganisms in the absence of air. It has been severally defined by different researchers. Sincero and Sincero [13] say it is "a biological decomposition of organic waste done in the absence of air", while the Oregon State Department of Energy [14] presents it as "a biochemical process in which particular kinds of bacteria digest biomass in an oxygen-free environment". There are different types of bacteria that work together to break down complex organic wastes in stages, resulting in the production of biogas. Hence, Chawla [15] says anaerobic digestion is "a bioreactor in which organic matter is progressively degraded in the absence of oxygen by a process known as methanogenesis". This latter definition seems a bit of course, as AD is actually a process and not the facility for the process.

Anaerobic digestion has been widely used for the treatment of industrial, agricultural and municipal waters and sludge. This accounts for Hobson et al [16] defining AD as a method of stabilizing, and thus reducing pollution from the sewage sludge produced in several treatment works; and Reynolds and Richards [17] say it is the "biological oxidation of degradable organic sludge by microbes under anaerobic conditions". Kiely [18] and Vassilliou [19] explain that recently anaerobic digestion is also being applied to the treatment of municipal solid waste. Thus, Kiely [18] defines $\mathrm{AD}$ more holistically as "the use of microbial organisms in the absence of oxygen, for the stabilization of organic materials by conversion to methane and inorganic products, including carbon dioxide". So, anaerobic digestion evolved originally and primarily as a waste treatment process, with biogas generated only as a "waste product"

\subsection{Microbiology of the Anaerobic Process}

The AD process consists mainly of organic waste and bacteria interacting in an airtight enclosure called anaerobic digester. The organic waste is the food source for the bacteria, which convert it into the various end products and by-products. Different types of bacteria, referred to as facultative anaerobes and described as obligate anaerobes during methanogenesis, are involved in the process at different stages.

The entire process is complex, occurring in three basic stages, with four isolated trophic microbiological groups. The three stages are i) liquefaction of solids; ii) digestion of soluble solids, and iii) gas production [17]. According to Kiely [18], the cumulative effect of the four metabolic stages ensures continuity and stability of the AD process. Stewart [20] enlist several authors who have described AD as a three phase-, four phase-, five phase- and nine phase processes respectively; stating that the variations are indicative of the complexity of the microbial systems involved in the process. The generally predominant four stages are:
- Hydrolysis: - The breakdown of complex polymeric materials like proteins, carbohydrates, lipids, fats and grease by extracellular enzymes into simpler soluble products, small enough to pass through the cell membrane of the microorganism.

- Acidogenesis: - Where the lower molecular components of fatty acids, amino acids and monosaccharides are fermented to short-chain fatty acids, alcohols, ammonia, hydrogen and carbon dioxide.

- Acetogenesis: - This is often considered as a part of acidogenesis. The short-chain fatty acids are converted to acetate, hydrogen, and carbon dioxide

- Methanogenesis: - This is the final stage of methane production from hydrogen by hydrogenophillic methanogens and from acetate by aceticlastic methanogens.

A representation of the flow of these AD stages is shown in Figure 2.



Figure 2. Stages in methane production from organic waste Adopted from [18].

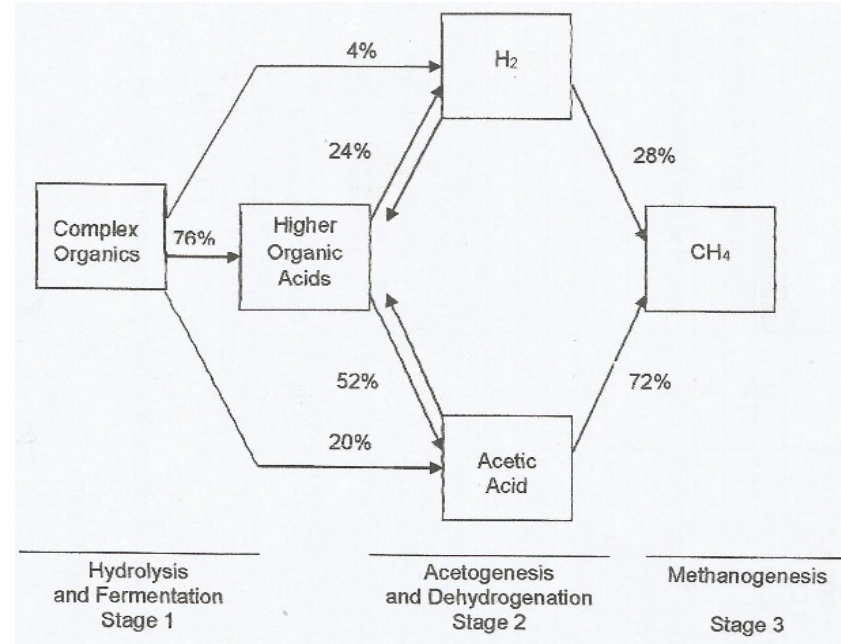

Figure 3. Carbon and hydrogen flow in anaerobic digestion process Adopted from [21] 
Eckenfelder [21] further explained that during hydrolysis, there is no reduction of the chemical oxygen demand (COD); but during the conversion of the monomers to volatile fatty acids (VFAs) there is minimal reduction of COD. However, when the organic acids are broken down to $\mathrm{CH}_{4}$ and $\mathrm{CO}_{2}$, there is considerable reduction of COD. A schematic of the carbon and hydrogen flow in the anaerobic digestion process is shown in Figure 3. The percentages indicated on the arrows show the extent of conversion of those components in the direction of the arrows.

The breakdown of carbohydrates, nitrogenous compounds and fats can simply be expressed using chemical formula as follows:

$$
\mathrm{C}_{6} \mathrm{H}_{12} \mathrm{O}_{6}+2 \mathrm{H}_{2} \mathrm{O} \rightarrow 2 \mathrm{C}_{2} \mathrm{H}_{4} \mathrm{O}_{2}+2 \mathrm{CO}_{2}+4 \mathrm{H}_{2}
$$

Then methane production is represented by equations (2) and (3)

$$
\begin{gathered}
2 \mathrm{C}_{2} \mathrm{H}_{4} \mathrm{O}_{2} \rightarrow 2 \mathrm{CH}_{4}+2 \mathrm{CO}_{2} \\
4 \mathrm{H}_{2}+2 \mathrm{CO}_{2} \rightarrow \mathrm{CH}_{4}+2 \mathrm{H}_{2} \mathrm{O}
\end{gathered}
$$

The generalized equation for the anaerobic digestion process is obtained as follows $[17,18]$ :

$$
\begin{aligned}
& \underset{\text { matter }}{\text { Organic }}+\underset{\text { water }}{\stackrel{\text { Combined Anaerobic New }}{\overrightarrow{\text { microbes cells }}}}+\begin{array}{c}
\text { Energy } \\
\text { for cells }
\end{array}+ \\
& \mathrm{CH}_{4}+\mathrm{CO}_{2}+\begin{array}{l}
\text { Other end } \\
\text { products }
\end{array}
\end{aligned}
$$

\subsection{Objective of the Study}

The $\mathrm{AD}$ process is carried out either in a batch or continuous system. Igoni [22] investigated the anaerobic processes in a continuous bioreactor for the simulation of biogas from municipal solid waste and formulated models to characterize the processes. This paper presents models for anaerobic biodegradation of MSW in a continuously stirred tank bioreactor for the production of biogas, to aid and facilitate designs of such bioreactors.

\section{Materials and Method}

\subsection{Reactor Experimentation}

Bench-scale experiment was conducted to investigate the behavior of municipal solid waste in anaerobic digestion [22]. Five batch-wise anaerobic digesters, of 5 liters' volume each, were set up for the experiment. A schematic diagram of the experimental design layout for a single batch reactor set-up is shown in Figure 4.

The digesters were improvised with large cans, because of the limitation of the unavailability of model digesters, deriving substantial impetus from Hobson et al. [17], who said "with a batch digester a smaller experimental system may be suitable as the digester has only to be loaded once and may not even need to be stirred. One or two liters could be big enough". The containers were properly lagged with wool material of about $25 \mathrm{~mm}$ thickness, to reduce interactions between inside and outside temperatures of the digesters.

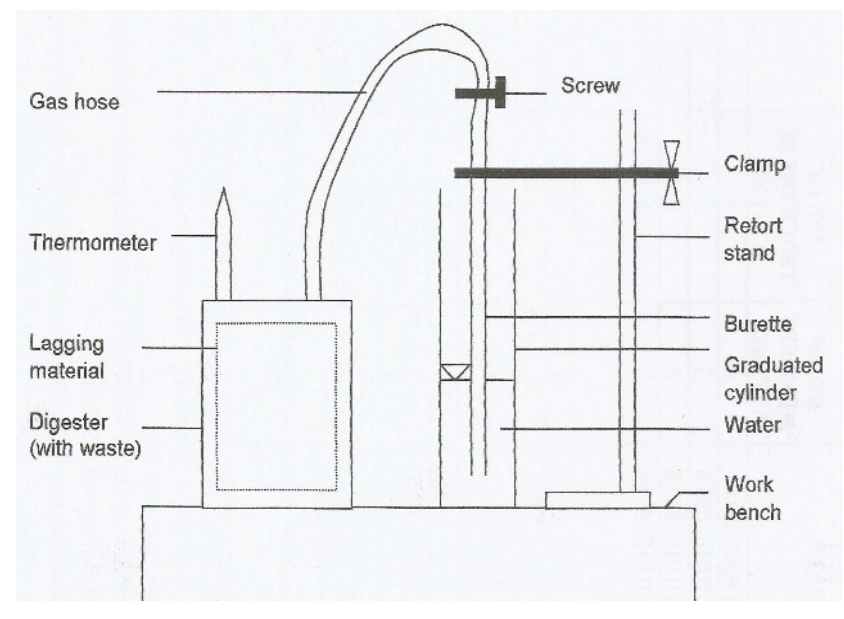

Figure 4. Schematic diagram of batch reactor experimentation design layout

Two perforations were made on the cover of the digester through which the gas hose and thermometer were fitted. The hose extending from the digester top was connected to the tail of a burette, which in turn was then partly immersed in water in a graduated cylinder. The waste materials were processed (shredded and mashed), and the digesters were then loaded with $2 \mathrm{~kg}$ of organic MSW, diluted to $26.7 \%$ total solids (TS) concentration.

The properties of MSW relevant to its anaerobic biodegradation was investigated and presented by Igoni et al. [1]. The TS concentration was determined by adopting the procedure for the determination of TS outlined in 2540 $G$ of Standard Methods for the Examination of Water and Waste Water [23]; and the moisture content was determined by the oven-drying method.

The $\mathrm{pH}$ was measured from a digital $\mathrm{pH}$ meter, and the substrate and biomass concentrations, were respectively determined in terms of the chemical oxygen demand (COD), and the mixed liquor volatile suspended solids (MLVSS) using the respective procedures in $5220 \mathrm{~b} .4 \mathrm{~b}$ and $2540 \mathrm{G}$ of Standard Methods for the Examination of Water and Waste Water. The carbon and nitrogen contents were determined, from where the carbon to nitrogen $(\mathrm{C}: \mathrm{N})$ ratio was computed. The carbon was determined by adapting the Walkley-Black method for determining soil organic matter [24], and the nitrogen was determined with macro-Kjedahl method. The thermometer, was passed into the headspace of the digester, and measured the temperature of the headspace inside of the digester. The ambient temperature was measured from maximum and minimum thermometers at the same time. These temperature measurements were taken at 0800 hours and 1400 hours, and aimed at determining temperature variation within and outside the digester, to ensure proper digester insulation with respect to digester construction materials. After these initial measurements 
from the waste replications, the digesters were made airtight with glue and other adhesives, and the set-up allowed running. Each of the digesters was dismantled at intervals of 5 days, which gave the experimentation a total lifespan of 25 days. At each dismantling, substrate (COD) and microbial (MLVSS) concentration measurements were repeated. The full view of the reactor experimentation set-up is shown in Figure 5.

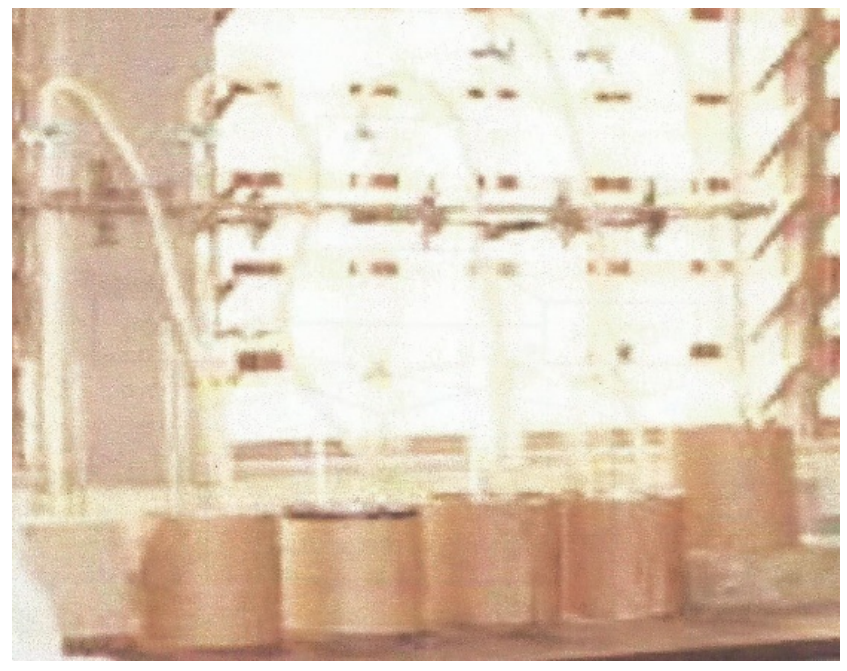

Figure 5. Full view of digesters experimental set-up

\subsection{Rate Equation for the Anaerobic Digestion Process}

In mixed cultures undergoing anaerobic digestion, the biomass degradation rather than the number of organism is of essence. With ' $X$ ' as the mixed population of microorganisms utilizing the organic waste, the rate of increase in biomass, which is proportional to the initial biomass concentration, is modelled as a first-order process $[18,13]$. The first order process is described with the rate equation (5).

$$
r_{x}=\frac{d[X]}{d t}=\mu[X]
$$

where

$$
\mathrm{r}_{\mathrm{x}}=\frac{d[X]}{d t}=\text { growth rate of biomass, } \mathrm{mg} \mathrm{l}^{-1} \mathrm{~d}^{-1}
$$

$\mathrm{X}$ - concentration of biomass, $\mathrm{mg}^{-1}$

$\mu$ - specific growth rate of the mixed population, $d^{-1}$

$=$ mass of cells produced $/$ mass of cells present per unit time

$\mathrm{t}$ - time, $\mathrm{d}$

By first-order kinetics, if $\mathrm{X}_{\mathrm{o}}$ represents the biomass at time, $\mathrm{t}=0$, then

$$
\int_{x_{o}}^{x} \frac{d[X]}{[X]}=\mu \int_{0}^{t} d t
$$

integrating:

$$
\begin{gathered}
\operatorname{In}[X]=\operatorname{In}\left[X_{o}\right]+\mu t \\
\operatorname{In}\left(\frac{[X]}{\left[X_{o}\right]}\right)=\mu t \\
{[X]=\left[X_{0}\right] \operatorname{Exp}(\mu t)}
\end{gathered}
$$

Using a conversion parameter called the fractional conversion $(\alpha)$, which is the 'fraction of the reactant converted to the product' [25], such that if $X_{o}$ be the initial concentration of the reactant, and $\mathrm{X}$ is the concentration of the reactants at any point in time, $t$, then the conversion of the reactants in a constant-volume system is given as equation (10).

$$
\begin{gathered}
\alpha=\frac{X_{o}-X}{X_{o}}=1-\frac{X}{X_{o}} \\
\text { and } \quad d \alpha=\frac{d X}{X_{o}}
\end{gathered}
$$

Considering the rate equation in terms of the fractional conversion gives

$$
\frac{d \alpha}{d t}=\mu(1-\alpha)
$$

Which upon rearrangement and integration becomes:

$$
\begin{gathered}
\int_{0}^{\alpha} \frac{d \alpha}{1-\alpha}=\mu \int_{0}^{t} d t \\
\text { or } \quad-\ln (1-\alpha)=\mu t
\end{gathered}
$$

and a plot of $\ln (1-\alpha)$ or $\ln \left(\frac{X}{X_{o}}\right)$ against time is expected to produce a straight line through the origin.

\subsection{Bacteria Growth Pattern in Continuous Culture}

Hobson et al [16] state that the simplest form of continuous culture also called the chemostat culture is a tank with inflow of medium and outflow of bacteria, metabolic products and depleted medium. They explain that the theoretical model formulation for continuous culture was originally proposed by Herbert et al [26] based on the Monod [27] description of bacterial growth in pure cultures.

The general form of the Monod equation is:

$$
\mu=\mu_{\max } \frac{[S]}{K_{s}+[S]}
$$

where:

$\mu_{\max }$ - maximum growth rate, $\mathrm{d}^{-1}$ 
$\mathrm{S}$ - concentration of limiting substrate, $\mathrm{mg} \mathrm{l}^{-1}$

$\mathrm{K}_{\mathrm{s}}$ - half saturation constant (i.e concentration of $\mathrm{S}$ when $\mu$ $=\mu_{\max } / 2\left(\mathrm{mg} \mathrm{l}^{-1}\right)$

Combining equation (15) with (14) relates the fractional conversion to both the maximum growth rate of biomass and the substrate concentration thus:

$$
-\ln (1-\alpha)=\mu_{\max } \frac{[S]}{K_{s}+[S]} t
$$

As the fresh medium flows into the charged tank, there is an interaction between the incoming medium and the residual charge described by a dilution rate (D) of the culture, which represents the inverse of the detention time of medium and bacteria in the system [16] and defined by Bailey and Ollis [28] as the number of tank volumes which pass through the vessel per unit time; and this corresponds to the concept of space-velocity presented by Levenspiel [25].

$$
\text { Therefore } \quad \mathrm{D}=\frac{Q}{V}=\frac{1}{\theta}
$$

where

$\mathrm{D}$ - dilution rate, $\mathrm{d}^{-1}$

$\mathrm{Q}$ - flow rate of medium, $\mathrm{m}^{3} \mathrm{~d}^{-1}$

$\mathrm{V}$ - volume of the culture, $\mathrm{m}^{3}$

From equation (5) $\frac{d(X)}{d t}=\mu[X]$, it has been shown that the bacteria are growing in the culture at a rate of $\mu[\mathrm{X}]$. Considering the dilution rate, then, the bacteria are also flowing out of the culture at a rate of $\mathrm{D}[\mathrm{X}]$. This means that the rate of change of bacterial concentration will be given as:

$$
\frac{d[X]}{d t}=\mu[X]-D[X]
$$

Also the rate of change of the limiting substrate concentration $\left(\frac{d[S]}{d t}\right)$ in the culture will be

$$
\frac{d[S]}{d t}=D\left[S_{o}\right]-D[S]-\frac{\mu[X]}{Y}
$$

where

$\mathrm{S}_{\mathrm{o}}$ - incoming substrate concentration, $\mathrm{mg}^{-1}$

$\mathrm{S}$ - out flowing substrate concentration, $\mathrm{mg}^{-1}$

$\mathrm{Y}$ - yield factor

$\mathrm{Ds}_{\mathrm{o}}$ - input rate, $\mathrm{d}^{-1}$

Ds - output rate, $\mathrm{d}^{-1}$

$\frac{\mu[X]}{Y}$ - rate of substrate consumption by bacteria, $\mathrm{mg}^{-1} \mathrm{~d}^{-1}$

Substituting for ' $\mu$ ' in equation (18) from equation (15), and neglecting cell death gives

$$
\frac{d[X]}{d t}=\mu_{\max }[X]\left(\frac{[S]}{K_{S}+[S]}\right)-D[X]
$$

And substituting for ' $\mu$ ' in equation (19) from equation (15) gives;

$$
\frac{d[S]}{d t}=D\left[S_{o}\right]-D[S]-\frac{[X]}{Y} \mu_{\max }\left(\frac{[S]}{K_{S}+[S]}\right)
$$

Under steady - state conditions, where the concentration of either the biomass or substrate does not change with time,

$$
\frac{d[X]}{d t}=\frac{d[S]}{d t}=0
$$

Therefore, from equation (20), the steady state mass balance on the biomass becomes.

$$
\mu_{\max }[X]\left(\frac{[S]}{K_{S}+[S]}\right)-D[X]=0
$$

which gives $\quad[\bar{S}]=\frac{D K_{S}}{\left(\mu_{\max }-D\right)}$

Where $\bar{S}$ - substrate concentration of a sterile feed $\left(X_{o}=0\right)$; and from equation (19), the steady state mass balance on the substrate becomes

$$
D\left[S_{o}\right]-D[S]-\frac{[X]}{Y} \mu_{\max }\left(\frac{[S]}{K_{s}+[S]}\right)=0
$$

From where,

$$
[\bar{X}]=Y\left[S_{o}\right]-K_{S}\left(\frac{D}{\mu_{\max }-D}\right)
$$

$\bar{X}$ - biomass concentration of a sterile feed $(\mathrm{Xo}=0)$.

Equations (24) and (26) show that the parameters $\mathrm{S}$ and $\mathrm{X}$ are clearly dependent on the flow rate $\left(D=\frac{Q}{V}\right)$ at steady state conditions.

From equation (18), considering steady state conditions, then

$$
[X](\mu-D)=0
$$

Which shows that at steady state $\mu=D$, implying that the rate of growth of biomass equilibrates the rate at which the medium passes through the system, indicating that a non-zero cell population can only be maintained at steady state. Hobson et al [16] further define a critical or washout dilution rate $D_{c}$ as:

$$
D_{C}=\mu_{\max }\left(\frac{\left[S_{o}\right]}{K_{S}+\left[S_{o}\right]}\right)
$$

As ' $D$ ' tends to ' $D_{c}$ ', the culture will washout because $[X]$ will drop drastically since no substrate will be used for biomass growth because $\mu$ and [S] are at their highest possible values. So, the critical dilution rate describes the level of dilution at which the culture will washout before there was any digestion. The diagram in Figure 6 is a graphical representation of bacterial growth pattern in a continuous culture with one growth limiting substrate. Curve 
$a-a$ is the theoretical curve, while curve ' $b$ ' is a semblance of a practical result because of maintenance and other effects.

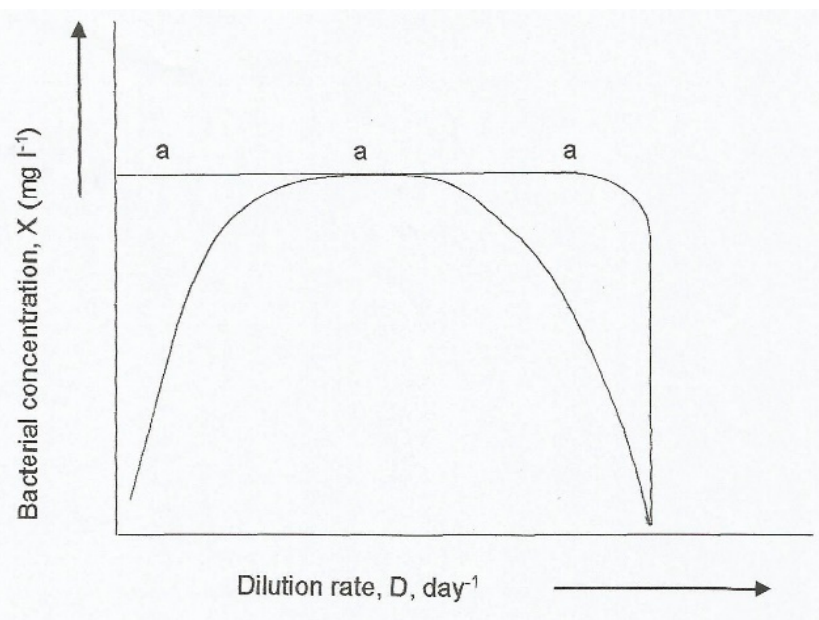

Figure 6. Bacterial growth pattern in continuous culture, Adopted from [16]

\subsection{Substrate Kinetics}

The fundamental proposition of substrate kinetics is that, as organisms grow substrates are consumed; so that the rate of decrease in substrate concentration is proportional to the rate of increase of the concentration of the organism [17]. Therefore, in terms of the net growth rate of biomass, equation (16) becomes

$$
-\ln (1-\alpha)=\left[\mu_{\max } \frac{[S]}{K_{s}+[S]}-k_{d}\right] t
$$

Assuming that all the substrate could be converted into biomass, the rate of decrease of the substrate will be described as:

$$
-\frac{d[S]}{d t}=\frac{d[X]}{d t}
$$

But practically this idealization is not feasible due to inefficiencies in the conversion process. However, introducing proportionality constant, $\mathrm{U}$, gives the following relationship, which is of a more practical relevance.

$$
\begin{gathered}
-\frac{d[S]}{d t}=U \mu_{\max } \frac{[S]}{K_{S}+[S]}[X]-k_{d}[X] \\
\text { or }-\frac{d[S]}{d t}=\frac{1}{Y} \mu_{\max } \frac{[S]}{K_{S}+[S]}[X]-k_{d}[X]
\end{gathered}
$$

where

U - specific substrate utilization rate

These formulations are depicted graphically in Figure 7.

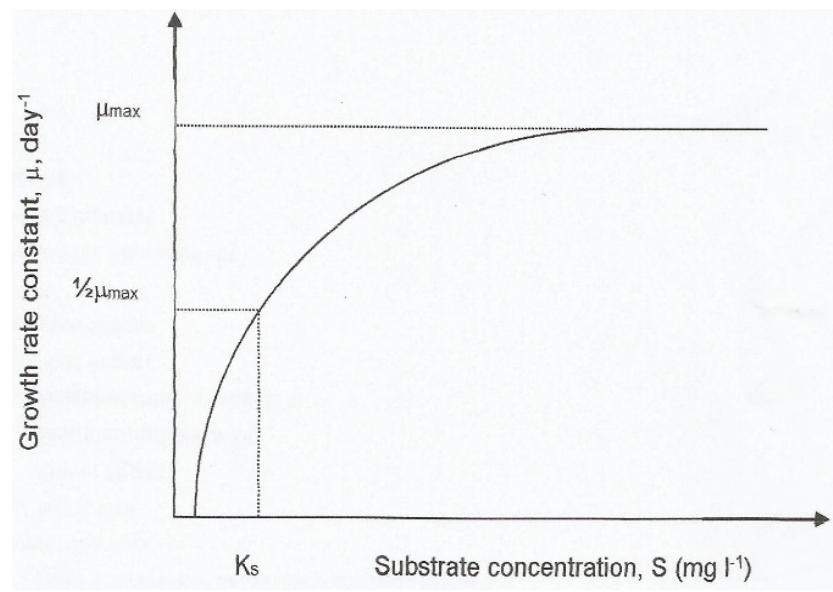

Figure 7. Relationship between the growth constant, $\mu$, and the substrate concentration, S Adopted from [17]

\subsection{Material Balance of the Anaerobic Digestion Process}

The basic design approach for an anaerobic bioreactor is the formulation of models for the reactor process, based on an analysis of material balances during the processes. Several literatures $[29,30,18,17,31]$ state the general form of a material balance expression as follows:

$$
\begin{array}{ccc}
\text { Rate of } & \text { Rate of } \\
\text { accumulation } & \text { Rate of } & \text { appearance or } \\
\text { of material in } & \text { material flow } \pm \text { disappearance } \\
\text { Reactor } & \text { into Reactor of material due } \\
\text { Rate of material } & \text { to Reaction } \\
\text { flow out of } \\
\text { Reactor }
\end{array}
$$

The simplified form of this expression is:

$$
\text { Accumulation }=\text { Inflow }+ \text { Net growth }- \text { Outflow }
$$

In the anaerobic digestion process, this expression can be symbolically presented as:

$$
\frac{d[X]}{d t} V_{r}=Q\left[X_{o}\right]+V_{r} \mu_{n e t}-Q[X]
$$

where

$$
\frac{d[X]}{d t} \text { - rate of change of microorganism concentration in }
$$
the reactor measured in terms of mass (Mixed Liquor Volatile Suspended Solids) ( $\left.\mathrm{mg} \mathrm{m}^{-3} \mathrm{~d}^{-1}\right)$

$$
\mathrm{V}_{\mathrm{r}} \text { - volume of reactor }\left(\mathrm{m}^{3}\right)
$$$$
\mathrm{Q} \text { - flow rate }\left(\mathrm{m}^{-3} \text { day }^{-1}\right)
$$

$\mathrm{X}_{\mathrm{o}}$ - concentration of microorganisms in influent (mg $\mathrm{m}^{-3}$ )

$\mathrm{X}$ - concentration of microorganism in reactor $\left(\mathrm{mg} \mathrm{m}^{-3}\right)$ $\mu_{\text {net }}$ - net rate of microorganisms' growth $\left(\mathrm{mg} \mathrm{m}^{-3}\right.$ day $\left.^{-1}\right)$ Since

$$
\mu_{n e t}=\mu_{\max } \frac{[S]}{K_{s}+[S]}[X]-k_{d}[X]
$$


Then, $\frac{d[X]}{d t} V_{r}=Q\left[X_{o}\right]+V_{r}\left(\mu_{\max } \frac{[S]}{K_{s}+[S]}[X]-k_{d}[X]\right)-Q[X]$

or $\frac{d[X]}{d t} V_{r}=Q\left(\left[X_{o}\right]-[X]\right)+V_{r}\left(\mu_{\max } \frac{[S]}{K_{s}+[S]}[X]-k_{d}[X]\right)$

\section{Results and Discussion}

\subsection{Laboratory Experimental Results}

The results from the batch experimentation for the anaerobic digestion of the municipal solid waste and the deduced data are presented in Tables 1-3.

This represents the general model for the anaerobic digestion process.

Table 1. Experimental batch digesters' data

\begin{tabular}{cccccc}
\hline Digester no. & $\begin{array}{c}\text { Duration of } \\
\text { digestion, } \mathrm{t} \\
\text { (days) }\end{array}$ & $\begin{array}{c}\text { Initial MSW } \\
\text { concentration, So (mg/l) }\end{array}$ & $\begin{array}{c}\text { Effluent MSW } \\
\text { concentration, Se (mg/l) }\end{array}$ & $\begin{array}{c}\text { Initial microbial } \\
\text { concentration, Xo } \\
(\mathrm{mg} / \mathrm{l})\end{array}$ & $\begin{array}{c}\text { Effluent microbial } \\
\text { concentration, Xe (mg/l) }\end{array}$ \\
\hline- & 0 & 462.12 & - & 32.05 & - \\
1 & 5 & 462.12 & 328.77 & 32.05 & 114.31 \\
2 & 10 & 462.12 & 78.71 & 32.05 & 206.45 \\
3 & 15 & 462.12 & 26.49 & 32.05 & 137.45 \\
4 & 20 & 462.12 & 13.19 & 32.05 & 127.89 \\
5 & 25 & 462.12 & 5.43 & 32.05 & 12.87 \\
\hline
\end{tabular}

Table 2. Reduced data from batch experimentation for the determination of process kinetic parameters

\begin{tabular}{cccccccc}
\hline Digester no. & $\begin{array}{c}\text { Duration of } \\
\text { digestion, t (days) }\end{array}$ & $\bar{X}$ & $\bar{X} t$ & $\ln \left(\frac{S_{o}}{S_{e}}\right)$ & $\mathrm{S}_{\mathrm{o}}-\mathrm{S}_{\mathrm{e}}$ & $\frac{S_{o}-S_{e}}{\bar{X} t}$ & \multicolumn{1}{l}{$\ln \left(\frac{S_{o}}{S_{e}}\right) / \bar{X} t$} \\
\hline- & 0 & - & 0 & 0 & - & - & - \\
1 & 5 & 73.18 & 365.9 & 0.340 & 133.35 & 0.364 & 0.000929 \\
2 & 10 & 119.25 & 1192.50 & 1.770 & 383.41 & 0.322 & 0.00148 \\
3 & 15 & 84.75 & 1271.25 & 2.859 & 435.63 & 0.343 & 0.00225 \\
4 & 20 & 79.97 & 1599.4 & 3.556 & 448.93 & 0.281 & 0.00222 \\
5 & 25 & 22.46 & 561.5 & 4.444 & 456.69 & 0.813 & 0.00791 \\
\hline
\end{tabular}

$\bar{X}=$ average cell mass concentration during the biochemical reaction - that is $\mathrm{X}=1 / 2(\mathrm{Xo}+\mathrm{Xt})$, where $\mathrm{Xo}$ and $\mathrm{Xt}$ are the cell mass concentrations at the respective times $\mathrm{t}=0$ and $\mathrm{t}=\mathrm{t}$ [18]

Table 3. Reduced data from batch experimentation for determination of CSTR parameters

\begin{tabular}{|c|c|c|c|c|c|c|}
\hline $\begin{array}{l}\text { Rate of MSW } \\
\text { utilization, } \\
\mathrm{ds} / \mathrm{dt}, \mathrm{mg} / \mathrm{l} / \text { day }\end{array}$ & $\begin{array}{c}\text { Specific rate of } \\
\text { MSW utilization, } U \\
\text { day }^{-1}\end{array}$ & $1 / \mathrm{U}$ & $\begin{array}{c}\text { Rate of growth of } \\
\text { microbes, } \\
\mathrm{dx} / \mathrm{dt}, \\
\mathrm{mg} / \mathrm{l} / \mathrm{day}\end{array}$ & $\begin{array}{c}\text { Mean cell } \\
\text { residence time, } \theta, \\
\text { days }\end{array}$ & $1 / \theta$ & $1 / \mathrm{Se}$ \\
\hline 0 & 0 & 0 & 0 & - & - & - \\
\hline 41.72 & 0.570 & 1.754 & 16.45 & 4.444 & 0.225 & 0.00304 \\
\hline 25.58 & 0.215 & 4.662 & 17.44 & 6.849 & 0.146 & 0.0127 \\
\hline 6.25 & 0.074 & 13.56 & 7.03 & 12.06 & 0.0829 & 0.0378 \\
\hline 4.66 & 0.058 & 17.16 & 4.79 & 16.67 & 0.060 & 0.0758 \\
\hline 0.56 & 0.025 & 40.11 & $(0.767)$ & 29.41 & 0.034 & 0.1842 \\
\hline
\end{tabular}

These results (Tables 1-3) were used for the determination of the bio-kinetic parameters of the MSW [32] relevant to the simulation of the digestion process. 


\subsection{Development of the Continuous Processing Models}

The models adopted the general form of the material balance expression for a CSTR, since the aggregate characteristics of the CSTR including its flow regime was considered in the developing the model.

(I) Material balance for mass of microorganism

The mass balance for the mass of microorganisms in a complete-mix reactor, will, therefore be:

$$
\frac{d[X]}{d t} V_{c}=Q\left(\left[X_{o}\right]-[X]\right)+V_{c}\left(\mu_{\max } \frac{[S]}{K_{S}+[S]}[X]-k_{d}[X]\right)
$$

Now, considering steady state condition, i.e. $\frac{d[X]}{d t}=0$, and assuming that Xo is negligible at the commencement of the process, then equation (37) becomes

$$
Q[X]=V_{c}\left(\mu_{\max } \frac{[S]}{K_{S}+[S]}[X]-k_{d}[X]\right)
$$

or (eliminating [X])

$$
Q=V_{c}\left(\mu_{\max } \frac{[S]}{K_{S}+[S]}-k_{d}\right)
$$

But $\frac{V_{c}}{Q}$ is defined as the mean cell residence time $(\theta c)$. Therefore

$$
\begin{gathered}
\frac{1}{\theta_{C}}=\mu_{\max } \frac{[S]}{K_{S}+[S]}-k_{d} \\
\text { or } \frac{1}{\theta_{c}}=\frac{\mu_{\max }[S]-k_{d}\left(K_{S}+[S]\right)}{K_{S}+[S]}
\end{gathered}
$$

(ii) Material balance for total substrate utilization

The mass balance for substrate utilization in a CSTR will be given as

$$
\begin{gathered}
V_{c} \frac{d[S]}{d t}=Q\left[S_{o}\right]+r_{S} V_{c}-Q[S] \\
V_{c} \frac{d[S]}{d t}=Q\left(\left[S_{o}\right]-[S]\right)+r_{s} V_{c}
\end{gathered}
$$

where $r_{s}$ - rate of substrate utilization, and defined mathematically as

$$
r_{s}=-\frac{k[S]}{K_{S}+[S]}[X]
$$

So, substituting for ' $\mathrm{r}_{\mathrm{s}}$ ' in equation (40b) from equation (41) and assuming steady-state conditions $\left(\right.$ i.e. $\left.\frac{d[S]}{d t}=0\right)$ gives

$$
Q\left(\left[S_{O}\right]-[S]\right)-\frac{k[S]}{K_{S}+[S]}[X] V_{c}=0
$$

or

$$
\begin{array}{r}
{\left[S_{o}\right]-[S]=\left(\frac{V_{c}}{Q}\right)\left(\frac{k[S]}{K_{S}+[S]}[X]\right)} \\
\therefore \quad\left[S_{o}\right]-[S]=\theta_{h} \frac{k[S]}{K_{S}+[S]}[X]
\end{array}
$$

where $\theta_{\mathrm{h}}=$ Hydraulic Retention Time, which is the same as the mean cell residence time $\left(\theta_{\mathrm{C}}\right)$ for no cell recycle anaerobic systems and describes the digestion time for the CSTR, such that from equation ...

$$
\therefore \quad \theta_{h}=\frac{\left(\left[S_{o}\right]-\left[S_{e}\right]\right)\left(K_{s}+\left[S_{e}\right]\right.}{k\left[S_{e}\right][X]}
$$

From equation (39a)

$$
\frac{[S]}{K_{S}+[S]}=\frac{1}{\mu_{\max }}\left(\frac{1}{\theta_{C}}+k_{d}\right)
$$

and from equation $(42 \mathrm{c})$,

$$
\frac{[S]}{K_{S}+[S]}=\frac{\left[S_{o}\right]-\left[S_{e}\right]}{\theta_{h} k[X]}
$$

Therefore, combining equations (44) and (45) gives

$$
\begin{gathered}
\frac{[S]-\left[S_{e}\right]}{\theta_{h} k[X]}=\frac{1}{\mu_{\max }}\left(\frac{1}{\theta_{C}}+k_{d}\right) \\
{\left[S_{o}\right]-[S]=\frac{\theta_{h} k}{\mu_{\max }}\left(\frac{1}{\theta_{c}}+k_{d}\right)[X]} \\
\quad \text { or }[X]=\frac{\mu_{\max }\left[S_{o}\right]-[S] \theta_{c}}{k\left(1+k_{d} \theta_{c}\right) \theta_{h}} \\
\quad \text { or }[X]=\frac{Y\left[S_{o}\right]-[S] \theta_{c}}{\left(1+k_{d} \theta_{c}\right) \theta_{h}}
\end{gathered}
$$

The maximum rate of substrate utilization, $\mathrm{k}$, is defined by the equation:

$$
k=\mu_{\max } / Y
$$

Rearranging equation (44) and substituting for $\mu_{\max }$ from equation (48):

$$
[S]=\frac{K_{S}\left(1+k_{d} \theta_{c}\right)}{\theta_{c}\left(Y k-k_{d}\right)-1}
$$

Again from equation (46b) 


$$
\begin{aligned}
& \frac{\left[S_{o}\right]-[S]}{[X] \theta_{h}}=\frac{1}{Y}\left(\frac{1+k_{d} \theta_{c}}{\theta_{c}}\right) \\
& \text { or } \frac{\left[S_{o}\right]-[S]}{[X] \theta_{h}}=\frac{1}{Y \theta_{c}}+\frac{k_{d}}{Y}
\end{aligned}
$$

And from combining equations (42c) and (50b), then

$$
\frac{\theta_{c}}{1+k_{d} \theta_{c}}=\frac{K_{s}}{[S] Y k}+\frac{1}{Y k}
$$

Considering the fractional conversion $(\alpha)$ of the substrate (S), defined as:

$$
\alpha=\frac{\left[S_{o}\right]-[S]}{\left[S_{o}\right]}
$$

$$
\text { Then }\left[S_{o}\right]=\frac{[S]}{(1-\alpha)}
$$

Substituting for $\left[\mathrm{S}_{\mathrm{o}}\right]$ in equation $(42 \mathrm{c})$ gives

$$
\begin{gathered}
\frac{[S]}{(1-\alpha)}-[S]=\theta_{h} \frac{k[S]}{K_{s}+[S]}[X] \\
\frac{[S]-[S](1-\alpha)}{(1-\alpha)}=\theta_{h} \frac{k[S]}{K_{s}+[S]}[X] \\
\theta_{h}=\frac{\left(K_{s}+[S]\right)\{[S]-[S](1-\alpha)\}}{k[S][X](1-\alpha)} \\
\theta_{h}=\frac{\alpha}{(1-\alpha)}\left[\frac{\left(K_{S}+[S]\right)[S]}{k[X][S]}\right] \\
\text { or } \theta_{h}=\frac{\alpha}{(1-\alpha)}\left[\frac{K_{s}+[S]}{k[X]}\right]
\end{gathered}
$$

\subsection{Validation of Models}

The theoretical models for the anaerobic continuous process were simulated over a range of fractional conversion factors of 0.2-0.8 and percentage total solids concentrations of 4-10, using Microsoft Visual Basic Version 6.0 programming language. The results of the process simulation are presented in Tables 4 to 7 . The simulation considered the effect of fractional conversion on the time required for digestion $\left(\mathrm{t}_{\mathrm{c}}\right)$, effluent substrate $\left(\mathrm{S}_{\mathrm{e}}\right)$ and microbial $\left(\mathrm{X}_{\mathrm{e}}\right)$ concentrations, volumes of methane $\left(\mathrm{V}_{\mathrm{mc}}\right)$ and biogas $\left(\mathrm{V}_{\mathrm{tc}}\right)$ produced, and effluent substrate stabilization $\left(\mathrm{E}_{\mathrm{c}}\right)$. It further established relationships between the time of digestion with effluent substrate and microbial concentrations. These relationships were analyzed mathematically using Microsoft
Chart Editor. Figures 8-14 present the graphical relationships between these parameters.

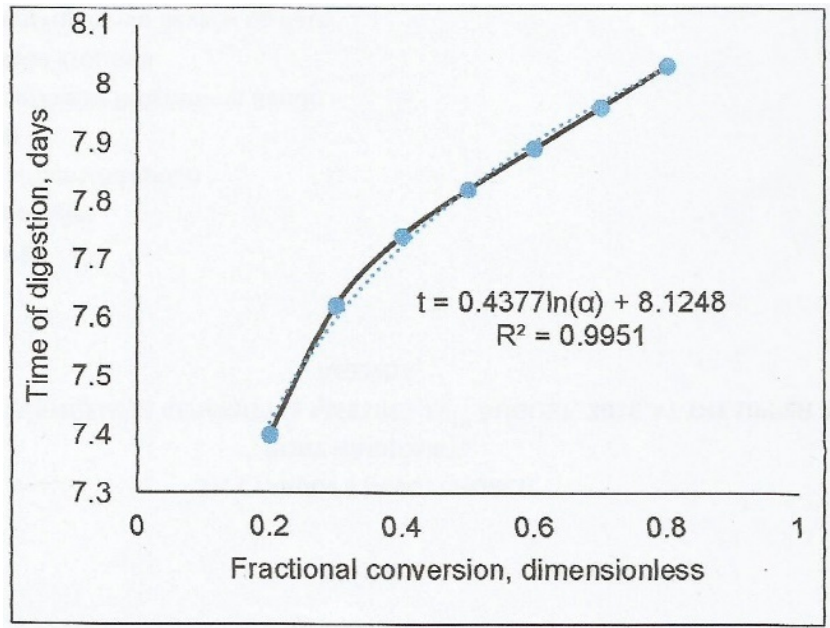

Figure 8. Effect of fractional conversion on time of digestion

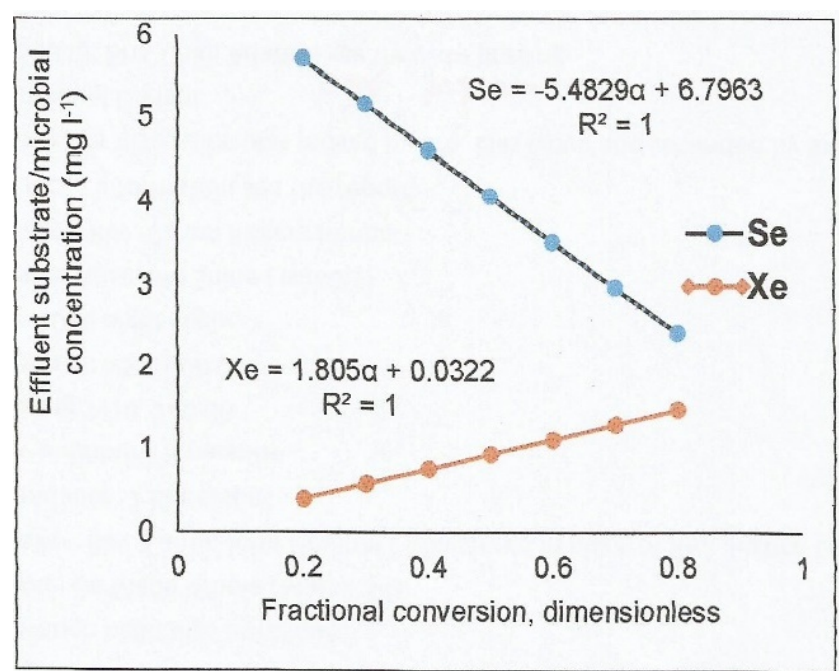

Figure 9. Effect of fractional conversion on effluent substrate and microbial concentration

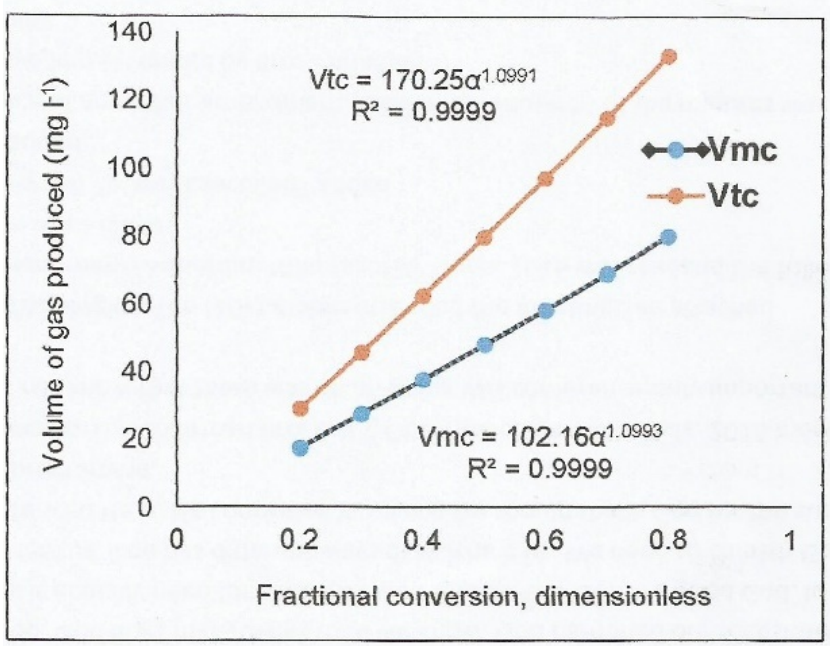

Figure 10. Effect of fractional conversion on Volumes of gas produced 


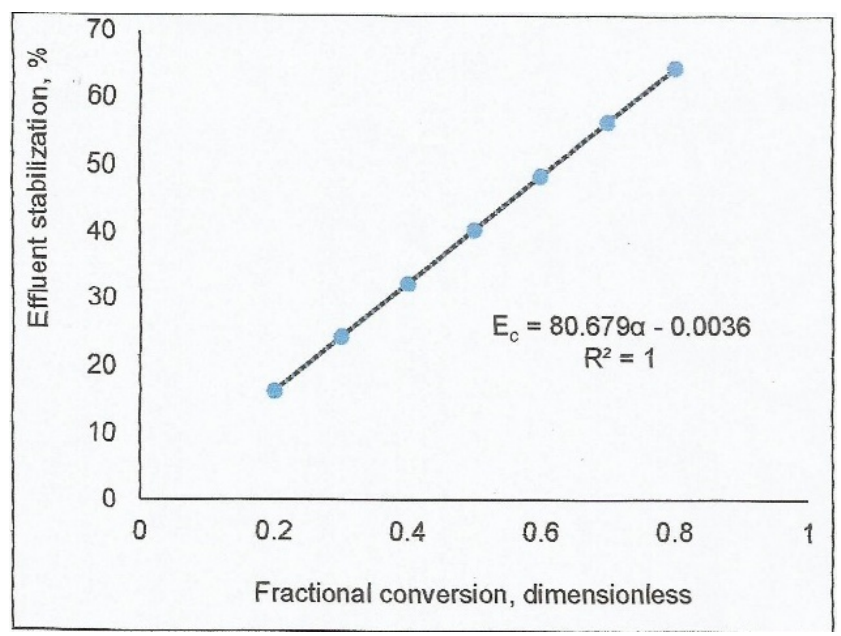

Figure 11. Effect of fractional conversion on effluent substrate stabilization

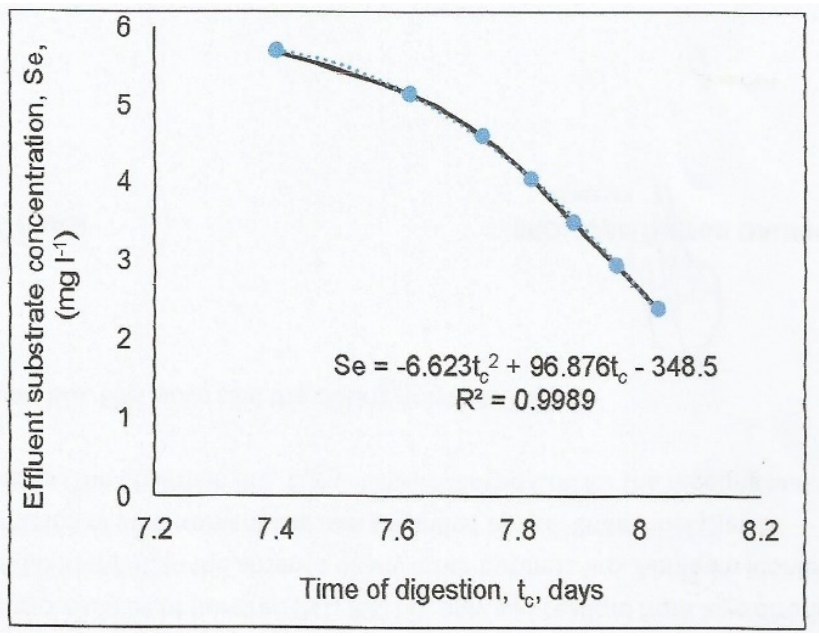

Figure 12. Variation of effluent substrate Concentration with time of digestion

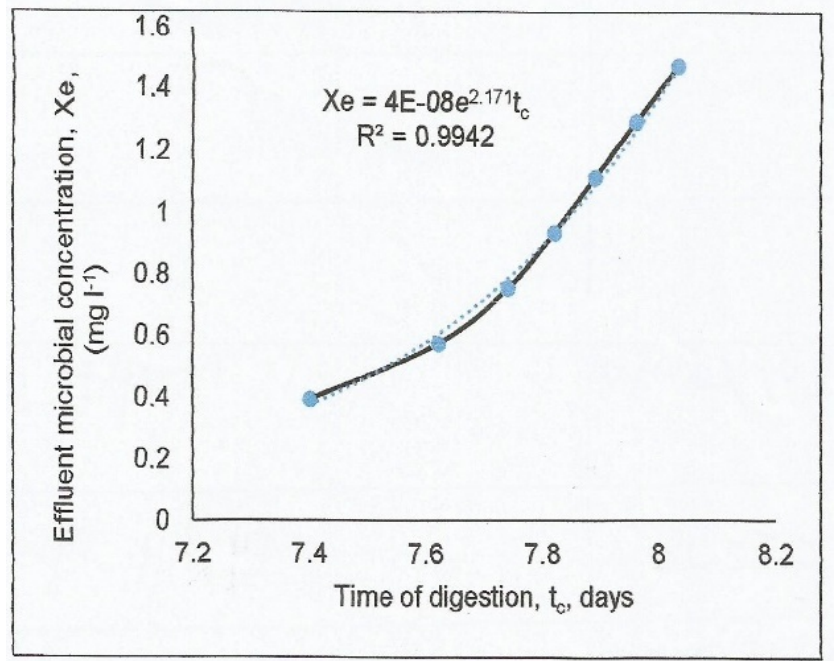

Figure 13. Variation of effluent microbial concentration with time of digestion

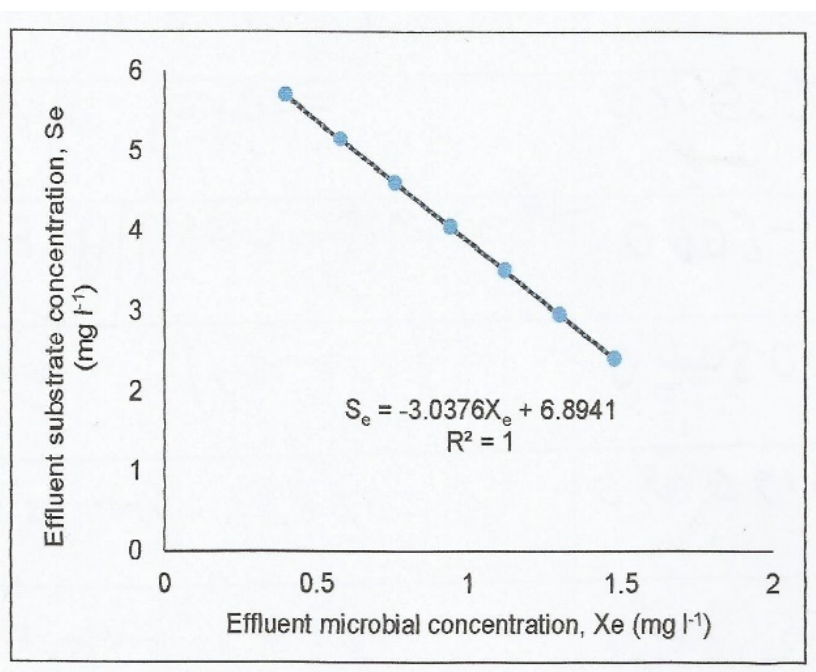

Figure 14. Relationship between effluent microbial and substrate concentrations

Figure 8 shows that the perfect correlation between the time of digestion and fractional conversion is a logarithmic function of the fractional conversion, such that the relationship between $t_{c}$ and $\alpha$ is established, as in equation (55). This logarithmic function corroborates the postulation of Levenspiel [25], that a plot of $\ln (1-\alpha)$ against time will yield a straight line passing through the origin.

$$
t_{c}=0.4311 \ln (\alpha)+8.1248
$$

From Figure 9, the effluent substrate concentration is a decreasing linear function of the fractional conversion, while the effluent microbial concentration is an increasing linear function. This, expectedly, shows that while a progression of the fractional conversion reduces the effluent substrate concentration, it simultaneously elicits an increase in the effluent microbial concentration. The models below describe these relationships:

$$
\begin{array}{r}
S_{e}=-5.4529 \alpha+6.7963 \\
\text { and } X_{e}=1.805 \alpha+0.0322
\end{array}
$$

The effect of fractional conversion on the volume of gas produced is described in Figure 10, while Fig. 11 describes its effect on the degree of stabilization of the effluent substrate. The total volume of gas and methane produced are both power functions of the fractional conversion, described by the equations:

$$
\begin{aligned}
& V_{t c}=170.25 \propto^{1.0991} \\
& V_{m c}=102.16 \propto^{1.0993}
\end{aligned}
$$

and the percentage effluent substrate stabilization is a linear function, thus:

$$
E_{c}=80.679 \alpha-0.0036
$$

The relationships between the effluent substrate and microbial concentrations with time of digestion respectively are shown in Figures 12 and 13. The perfect correlation is described by a polynomial of order 2 for the former, while the latter is a power function of the time of digestion. This 
situation is further depicted in the interrelationship between the effluent substrate and microbial concentrations (Figure 14), which is a linear function showing that reduction in substrate concentration directly translates to an increase in microbial growth and these are rate functions. The following models are established from the respective curves.

$$
\begin{gathered}
S_{e}=-6.623 t_{c}^{2}+96.876 t_{c}-348.5 \\
X_{e}=4 E-008 e^{2.17 t_{c}} \\
S_{e}=-3.0376 X_{e}+6.8941
\end{gathered}
$$

environment. The development of predictive models for the behavior of municipal solid waste in continuous anaerobic processing will largely mitigate the numerous damages done the environment by non-treatment, especially when the process involves the release of a gas that is an energy source. With the models, it is now possible to estimate the necessary interactions between process parameters; especially, the length of time a given waste load will spend in continuous processing to achieve a desired level of stabilization and the volume of gas produced.

\section{Conclusions}

\section{Appendix}

Treatment of municipal solid waste is a vital functional element of a waste management system. The absence of the treatment component in the waste management practices in

Simulation Results for the Continuous Anaerobic Digestion Process

Port Harcourt, Nigeria has caused several harm to the

Table 4. Summary of CSTR Parameters at $4 \% \mathrm{TS}(\mathrm{TS}=9971.44, \mathrm{VS}=6640.98)$

\begin{tabular}{|c|c|c|c|c|c|c|}
\hline$\alpha$ & $\begin{array}{c}\mathrm{S}_{\mathrm{e}} \\
\left(\mathrm{mg} \mathrm{l}^{-1}\right)\end{array}$ & $\begin{array}{c}\mathrm{X}_{\mathrm{e}} \\
\left(\mathrm{mg} \mathrm{l}^{-1}\right)\end{array}$ & $\begin{array}{c}t_{c} \\
\text { days }\end{array}$ & $\begin{array}{c}E_{c} \\
(\%)\end{array}$ & $\begin{array}{c}\mathrm{V}_{\mathrm{mc}} \\
\mathrm{m}^{3} \mathrm{CH}_{4} \mathrm{~d}^{-1}\end{array}$ & $\begin{array}{l}V_{t c} \\
m^{3}\end{array}$ \\
\hline 0.2 & 2.035 & 0.161 & 6.61 & 16.13 & 3.26 & 5.43 \\
\hline 0.3 & 1.839 & 0.226 & 7.11 & 24.20 & 5.56 & 9.27 \\
\hline 0.4 & 1.644 & 0.290 & 7.41 & 32.27 & 7.97 & 13.29 \\
\hline 0.5 & 1.449 & 0.354 & 7.62 & 40.34 & 10.48 & 17.46 \\
\hline 0.6 & 1.252 & 0.419 & 7.80 & 48.40 & 13.09 & 21.82 \\
\hline 0.7 & 1.056 & 0.483 & 7.97 & 56.47 & 15.86 & 26.43 \\
\hline 0.8 & 0.861 & 0.548 & 8.16 & 64.54 & 18.88 & 31.46 \\
\hline
\end{tabular}

\begin{tabular}{ccccccc}
\hline$\alpha$ & $\begin{array}{c}\mathrm{S}_{\mathrm{e}} \\
\left(\mathrm{mg} \mathrm{l}^{-1}\right)\end{array}$ & $\begin{array}{c}\mathrm{X}_{\mathrm{e}} \\
\left(\mathrm{mg} \mathrm{l}^{-1}\right)\end{array}$ & $\begin{array}{c}\mathrm{t}_{\mathrm{c}} \\
\text { days }\end{array}$ & $\begin{array}{c}\mathrm{E}_{\mathrm{c}} \\
(\%)\end{array}$ & $\begin{array}{c}\mathrm{V}_{\mathrm{mc}} \\
\mathrm{m}^{3} \mathrm{CH}_{4} \mathrm{~d}^{-1}\end{array}$ & $\begin{array}{c}\mathrm{V}_{\mathrm{tc}} \\
\mathrm{m}^{3}\end{array}$ \\
\hline 0.2 & 0.901 & 0.089 & 5.53 & 16.13 & 0.75 & 1.25 \\
0.3 & 0.814 & 0.118 & 6.34 & 24.20 & 1.44 & 2.40 \\
0.4 & 0.728 & 0.146 & 6.87 & 32.27 & 2.22 & 3.70 \\
0.5 & 0.641 & 0.175 & 7.29 & 40.34 & 3.07 & 5.12 \\
0.6 & 0.554 & 0.203 & 7.64 & 48.40 & 4.01 & 6.68 \\
0.7 & 0.468 & 0.232 & 7.99 & 56.47 & 5.06 & 6.43 \\
0.8 & 0.381 & 0.260 & 8.40 & 64.54 & 6.29 & 10.48 \\
\hline
\end{tabular}

Table 5. Summary of CSTR Parameters at $6 \% \mathrm{TS}(\mathrm{TS}=16208.81, \mathrm{VS}=10795.07)$

\begin{tabular}{|c|c|c|c|c|c|c|}
\hline$\alpha$ & $\begin{array}{c}\mathrm{S}_{\mathrm{e}} \\
\left(\mathrm{mg} \mathrm{l}^{-1}\right)\end{array}$ & $\begin{array}{c}\mathrm{X}_{\mathrm{e}} \\
\left(\mathrm{mg} \mathrm{l}^{-1}\right)\end{array}$ & $\begin{array}{c}t_{\mathrm{c}} \\
\text { days }\end{array}$ & $\begin{array}{c}E_{c} \\
(\%) \\
\end{array}$ & $\begin{array}{c}\mathrm{V}_{\mathrm{mc}} \\
\mathrm{m}^{3} \mathrm{CH}_{4} \mathrm{~d}^{-1}\end{array}$ & $\begin{array}{l}V_{\text {tc }} \\
\mathrm{m}^{3} \\
\end{array}$ \\
\hline 0.2 & 3.633 & 0.262 & 7.13 & 16.13 & 8.49 & 14.14 \\
\hline 0.3 & 3.283 & 0.377 & 7.45 & 24.20 & 13.76 & 22.93 \\
\hline 0.4 & 2.934 & 0.492 & 7.63 & 32.27 & 19.14 & 31.91 \\
\hline 0.5 & 2.585 & 0.607 & 7.76 & 40.34 & 24.64 & 41.06 \\
\hline 0.6 & 2.235 & 0.723 & 7.86 & 48.40 & 30.26 & 50.44 \\
\hline 0.7 & 1.886 & 0.838 & 7.96 & 56.47 & 36.08 & 60.13 \\
\hline 0.8 & 1.536 & 0.953 & 8.07 & 64.54 & 42.22 & 70.36 \\
\hline
\end{tabular}

Table 6. Summary of CSTR Parameters at $8 \%$ TS $(T S=23280.61$, VS $=15504.89)$ 
Table 7. Summary of CSTR Parameters at $10 \% \mathrm{TS}(\mathrm{TS}=31186.84, \mathrm{VS}=20770.43)$

\begin{tabular}{ccccccc}
\hline$\alpha$ & $\begin{array}{c}\mathrm{S}_{\mathrm{e}} \\
\left(\mathrm{m} \mathrm{l}^{-1}\right)\end{array}$ & $\begin{array}{c}\mathrm{X}_{\mathrm{e}} \\
\left(\mathrm{mg} \mathrm{l}^{-1}\right)\end{array}$ & $\begin{array}{c}\mathrm{t}_{\mathrm{c}} \\
\text { days }\end{array}$ & $\begin{array}{c}\mathrm{E}_{\mathrm{c}} \\
(\%)\end{array}$ & $\begin{array}{c}\mathrm{V}_{\mathrm{mc}} \\
\mathrm{m}^{3} \mathrm{CH}_{4} \mathrm{~d}^{-1}\end{array}$ & $\begin{array}{c}\mathrm{V}_{\mathrm{tc}} \\
\mathrm{m}^{3}\end{array}$ \\
\hline 0.2 & 5.700 & 0.393 & 7.40 & 16.13 & 17.31 & 27.34 \\
0.3 & 5.151 & 0.574 & 7.62 & 24.20 & 37.49 & 45.86 \\
0.4 & 4.603 & 0.754 & 7.74 & 32.27 & 47.75 & 62.48 \\
0.5 & 4.055 & 0.935 & 7.82 & 40.34 & 58.17 & 79.58 \\
0.6 & 3.507 & 1.115 & 7.89 & 48.40 & 68.82 & 96.95 \\
0.7 & 2.958 & 1.296 & 7.96 & 56.47 & 79.86 & 114.71 \\
0.8 & 2.410 & 1.476 & 8.03 & 64.54 & 133.10 \\
\hline
\end{tabular}

\section{REFERENCES}

[1] Igoni, A. H., Ayotamuno M. J., Ogaji, S. T., Probert, S. D.: Municipal Solid Waste in Port Harcourt, Nigeria. Applied Energy 84, (2007). 664-670

[2] Igoni, A. H.: Analyses of Anaerobic batch digestion of municipal solid waste in the production of biogas using mathematical models, Energy and Environment Research, Vol. 6, No. 1. Doi:10.5539/eer.v6n1p44. (2016). pp44-56

[3] Ayotamuno, M. J., Gobo, A. E.: Municipal Solid Waste Management in Port Harcourt, Nigeria: Obstacles and Prospects. Management of Environmental Quality: An International Journal, Vol. 15 No. 4. (2004) pp389 - 398.

[4] Getahun, T., Gebrehiwot, M., Ambelu, A., Van Gerven, T. and Van der Bruggen, B.: The potential of biogas production from municipal solid waste in a tropical climate. Environmental Monitoring Assessment, 186(7), DOI 10.1007/s10661-014-3727-4. (2014). pp 4637-4646

[5] Adeoti, O., Adegboyega, T. D., \& Ayelegun, T. A.: An assessment of Nigeria biogas potential from agricultural wastes. Energy Sources. Part, 23(1), (2001). 63-68.

[6] UNEP (2004). The use of economic instruments in environmental policy: opportunities and challenges, Geneva. (Accessed 13 Mar 2012).

[7] Sharholy, M., Ahmad, K., Mahmood, G., \& Trivedi, R. C.: Municipal solid waste management in Indian cities. A review Waste Management, 2 8(2), (2008), 459-467.

[8] Collivignarelli, C., Sorlini, S. and Vaccari, M.: Solid wastes management in developing countries, CD-ROM of ISWA 2004 World Congress, October 17-21, Rome, Italy (2004)

[9] Thorin, E., Daianova, L., Lindmark, J., Nordlander, E., Song, H., Jääskeläinen, A., Malo, L., den Boer, E., den Boer, J., Szpadt, R., Belous, O., Kaus, T. and Käger, M.: State of the Art in the Waste to Energy Area: Technology and Systems. Report no: O4.1.1 of REMOWE - Regional Mobilising of Sustainable Waste-to-Energy Production. (2011). 79pp

[10] Cheng, H. and Hu, Y. Municipal solid waste (MSW) as a renewable source of energy: Current and future practices in China. Bioresource Technology, 101(11), (2010). pp.3816-3824.

[11] Robert, O.A. and Reiner, L. The use of organic waste as an eco-efficient energy source in Ghana. Journal of
Environmental Protection, 3, (2012). pp.553-562.

[12] Baxter, D. and Seadl, T.: Anaerobic digestion of the organic fraction of MSW - system overview for source and central separated waste. IEA Bioenergy Exco71 workshop, South Africa. (2014).

[13] Sincero, A. P. and Sincero, G. A.: Environmental Engineering - A Design Approach. Prentice-Hall of India Private Limited, New Delhi. (1999). 795p.

[14] Oregon State Department of Energy. Biomass Energy Technology [online]; Available; www.oregondoe.org. (2002). $19 \mathrm{pp}$

[15] Chawler, O. P.: Advances in Biogas Technology, India Corporation of Agricultural Research. (1986) 28pp

[16] Hobson, P. N., Bousfield, S., Summers, R.: Methane Production from Agricultural and Domestic Wastes, Applied Science Publishers Ltd., London. (1981) .269pp

[17] Reynolds, T. D., Richards, P. A.: Units Operations and Processes in Environmental Engineering, second edition, PWS publishing company, Boston. (1996). 798p

[18] Kiely, G.: Environmental Engineering, International edition, Irwin McGraw-Hill, Boston. (1998) 979p

[19] Vassilliou, N.: "The Biogas Project of Cyprus", 1st International Conference of Energy and the Environment, Limassol, Cyprus. (1997) pp. 757-761.

[20] Stewart, W. C.: Three stage, multiple phase anaerobic digestion system and method US Patent 8765449 B2, filed July 31, 2009 and published July 1, 2014.

[21] Eckenfelder, W. W. Jr.: Industrial Water Pollution Control. McGraw-Hill Higher Education, Boston Burr Ridge. (2000) pp 394-411.

[22] Igoni, A. H.: Design of Anaerobic Bioreactors for Simulation of Biogas Production from Municipal Solid Waste. PhD Thesis of the Rivers State University of Science and Technology, Nigeria. (2006). 261pp

[23] American Public Health Association (APHA). Standard Methods for the Examination of Water and Wastewater, 19th Edition; Greenberg A. E. (Ed). Byrd Springfield, Washington D. C. (1995). 1100pp

[24] Walkley, A. and Black, I. A. An examination of the Degtjareff Method for Determining Soil Organic Matter and a Proposed Modification of the Chromic Acid Titration Method. Soil Science. 37, (1934), 29-37

[25] Levenspiel, O.: Chemical Reaction Engineering, (3rd Edition). 
John Wiley and Sons, Inc., New York. (1999) 668pp

[26] Herbert, D., Elsworth, R., Telling, R. C.: Journal of General Microbiology, 14, 601. (1956).

[27] Monod, J.: The Growth of Bacterial Cultures, Annual Review of Microbiology, Vol 111. (1949).

[28] Bailey, J. E., Ollis, D.F.: Biochemical Engineering Fundamentals; McGraw-Hill Book Publishers, New York, (1986). 753p.

[29] Tchobanoglous, G; Burton, F. L., Stensel, H. D.: Wastewater Engineering: Treatment and Reuse. Tata McGraw-Hill
Publishing Company Limited, New Delhi. (2003). 1819p

[30] Aguwamba, J. C.: Waste: Engineering and Management Tools. Immaculate Publications Ltd., Enugu, Nigeria. (2001). 572p

[31] Tchobanoglous, G; Burton, F. L. Wastewater Engineering: Treatment, Disposal and Reuse. Third edition. McGraw-Hill Inc., New York (1991). 1334p.

[32] Igoni, A. H., Abowei, M. F. N., Ayotamuno, M. J. and Eze, C. L. Biokinetics of anaerobic digestion of municipal solid waste. Newviews Engineering Analysis and Modelling, Vol. 1, No. 1. (2006). 98-112. 